\title{
EARTHQUAKES IN OWENS VALLEY, CALIFORNIA, JANUARY-FEBRUARY, 1959
}

\author{
By C. F. RICHTER
}

\begin{abstract}
In January, 1959, two series of small earthquakes originated in southern Owens Valley. The first and largest of these, of magnitude 4.7, originated on January 5, 12:36:02.9 GCT, near $36^{\circ} 09^{\prime} \mathrm{N}$, $118^{\circ} 03^{\prime} \mathrm{W}$, near Haiwee. This and other shocks of the series were well recorded by standard and strong-motion instruments at Haiwee, showing the characteristic false $\mathrm{S}-\mathrm{P}$ of about one second. The timing is good, and demonstrates that no change of supposed epicenter, depth, or velocities ean reasonably account for the second phase as $\mathrm{S}$. Other shocks were located at $36^{\circ} 07^{\prime} \mathrm{N}, 118^{\circ} 03^{\prime}$ $\mathrm{W}$, which probably represents the terminus of faulting in the first shocks.

A shock of magnitude 3.2 occurred on January 7 , at $00: 20: 40.2$ GCT near $35^{\circ} 46^{\prime} \mathrm{N}, 117^{\circ} 35^{\prime} \mathrm{W}$, near China Lake. This was followed by numerous others from the same source, mostly showing a false $\mathbf{S}$, and recorded by the Benioff instrument at China Lake down to very small magnitudes. However, shocks of this group of magnitude $0.7-0.8$ were more numerous than those of magnitudes $0.0-0.6$.

Initial compressions and dilatations in both groups of shocks were consistent, especially at the nearer stations, but lead to no simple fault-plane solutions.
\end{abstract}

ON JANUARY 5, 1959, at 12:36 GCT (4:36 PST) a moderately sharp earthquake was felt generally in southern Owens Valley and as far west as Porterville. It was followed by a long and numerous series of aftershocks extending into the following month. Instrumental data agree with macroseismic reports in placing the epicenters close to the recording station at Haiwee.

On January 7, 1959, at 00:20 GCT (January 6, 16:20 PST) another series of shocks commenced, with epicenters near the station at China Lake. Small shocks of this series were very numerous. The few larger ones were reported felt in the vicinity of China Lake. The locations of the epicenters are shown in figure 1.

\section{Earthquakes near Haiwee}

The series near Haiwee is of particular interest because of the presence there of low-magnification (strong-motion) instruments recording with good timing and showing for the larger shocks of that group an apparent $\mathrm{S}-\mathrm{P}$ interval near 1.5 seconds, as seen for the smaller ones on the recordings of the instruments with higher magnification (which show only the instant of arrival of $\mathbf{P}$ for the larger shocks).

Table 1 lists the shocks of this group with magnitude of 3.0 and over. Those marked $A$ are referred to an epicenter at $35^{\circ} 09^{\prime} \mathrm{N}, 118^{\circ} 03^{\prime} \mathrm{W}$; those marked $\mathrm{B}$ are referred to $35^{\circ} 07^{\prime} \mathrm{N}, 118^{\circ} 03^{\prime} \mathrm{W}$.

Tables 2 and 3 give travel times of $P$ for these shocks, and those of $S$ at the nearer stations, referred to the given origin times.

Analysis of the data for individual shocks is given as follows: table 4, largest shock, January 5, 12:36:02.9; table 5, shock of January 11, 18:54:58.1 (this shock

Manuscript received for publication October 7, 1959. 
has the advantage of being well observed at Woody, where the record of January 5 was defective); table 6 , shock of January 16, 00:10:05.9, representing the B epicenter.

Calculations were made assuming a hypocentral depth of $16 \mathrm{~km}$., P velocity $6.32 \mathrm{~km} / \mathrm{sec}$., Pn velocity $8.2 \mathrm{~km} / \mathrm{sec}$., and velocity ratio $\mathrm{P} / \mathrm{S}=1.732$. (S for King Ranch and other more distant stations was not used.) These are the usual routine assumptions for the area. It is clear that they do not fit the data well; in particular the apparent $\mathrm{S}-\mathrm{P}$ interval at Haiwee is irreconcilable with them. It should be noted that the origin time derived from this $\mathrm{S}-\mathrm{P}$ assuming the normal velocity

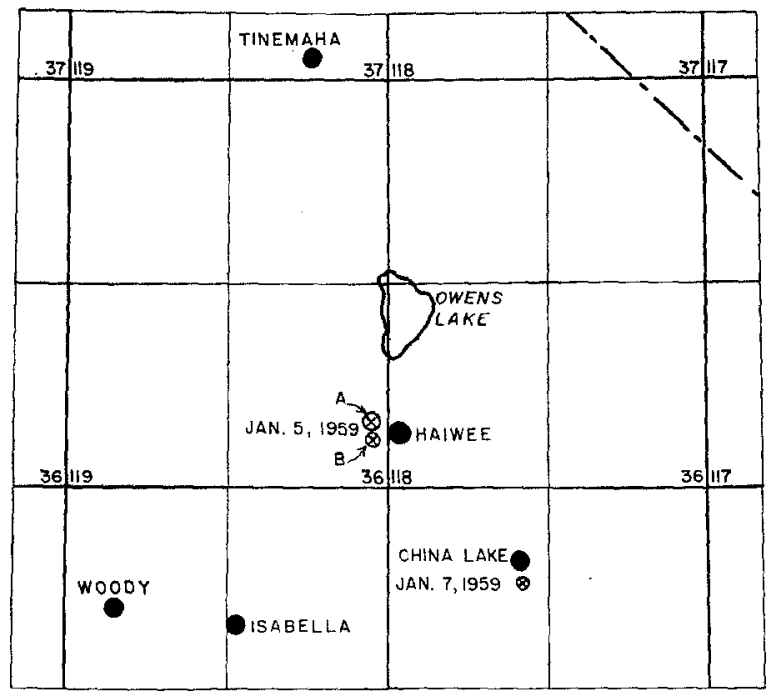

Fig. 1. Earthquakes in Owens Valley, California, January-February, 1959.

ratio disagrees with that similarly obtained from the other stations. In other words, the apparent $S$ at Haiwee, although it is a large, clear impulse, must be explained otherwise. This is one of many instances of the appearance of a false short $S-P$ at short epicentral distances.

The quantities in the columns headed $\mathrm{P}-\Delta / 8.2$ should be approximately constant for each shock, apart from variations due to different structure along different paths. Large values of this quantity are often due to missing a small first motion and measuring a later phase.

Representative means for $\mathrm{P}-\Delta / 8.2$ for tables $4,5,6$ respectively, are $10.0,5.5$, and 13.0. Subtracting the adopted origin times of the three shocks we find values for $K=\mathrm{P}-\Delta / 8.2-\mathrm{O}$ to be $7.1,7.4,7.1$ respectively. This result is common for shocks originating in the Owens Valley region, although the value of $K$ usually found over paths in the area including Pasadena is 5.6. The displacement between the $A$ and $B$ epicenters is determined more positively than the position of either, and indicates north-south faulting. Since the northern epicenter, A, must represent the point of initial faulting in the first large earthquake, the B epicenter may represent the terminal point in the same event, the total extent of faulting then being 3 to 4 kilometers. 
TABLE 1

Shocks of the Haiwee Grovp of Magnitude 3.0 and Over, Jandary-February, 1959, with Epicenters Near $35^{\circ} 09^{\prime} \mathrm{N}, 118^{\circ} 03^{\prime} \mathrm{W}$ (A) AND $35^{\circ} 07^{\prime} \mathrm{N}, 118^{\circ} 03^{\prime} \mathrm{W}$ (B)

\begin{tabular}{|c|c|c|c|}
\hline Date & Location & Time & Magnitude \\
\hline $\operatorname{Jan} .5 \ldots \ldots \ldots$ & A & $12: 36: 02.9$ & 4.7 \\
\hline \multirow[t]{2}{*}{ Jan. 6.} & B & $16: 10: 20.6$ & 3.7 \\
\hline & A & $23: 37: 08.4$ & 3.1 \\
\hline Jan. 7. & A & $03: 04: 57.7$ & 3.0 \\
\hline Jan. 11........ & A & $18: 54: 58.1$ & 3.7 \\
\hline Jan. $12 \ldots \ldots \ldots$ & $A$ & $12: 36: 05.6$ & 3.9 \\
\hline Jan. $16 \ldots$ & $\mathrm{B}$ & $00: 10: 05.9$ & 4.3 \\
\hline Jan. $17 \ldots$ & $A$ & $20: 05: 04.3$ & 3.3 \\
\hline Jan. $19 \ldots$ & $A$ & $21: 46: 00.5$ & 4.1 \\
\hline Feb. $4 \ldots$ & A & $15: 20: 45.3$ & 3.4 \\
\hline Feb. $8 \ldots \ldots \ldots$ & $\mathrm{B}$ & $08: 28: 55.7$ & 3.5 \\
\hline
\end{tabular}

TABLE 2

P and S Travel Times for Representative Shocks with Epicenter near $36^{\circ} 09^{\prime} \mathrm{N}, 118^{\circ} 03^{\prime} \mathrm{W}$, JANUARY-FEBRUARX, 1959

\begin{tabular}{|c|c|c|c|c|c|c|c|c|}
\hline $\begin{array}{l}\text { Date.............. } \\
\text { Origin time....... } \\
\text { Magnitude...... }\end{array}$ & $\begin{array}{c}\text { January } 5 \\
12: 36: 02.9 \\
4.7\end{array}$ & $\begin{array}{c}\text { January } 6 \\
23: 37: 08.4 \\
3.1\end{array}$ & $\begin{array}{c}\text { January } 7 \\
03: 04: 57.7 \\
3.0\end{array}$ & $\begin{array}{c}\text { January } 11 \\
18: 54: 58.1 \\
3.7\end{array}$ & $\begin{array}{c}\text { January } 12 \\
12: 36: 05.6 \\
3.9\end{array}$ & $\begin{array}{c}\text { January } 17 \\
20: 05: 05.3 \\
\mathbf{3 . 5}\end{array}$ & $\begin{array}{c}\text { January } 19 \\
21: 46: 00.5 \\
4.1\end{array}$ & $\begin{array}{c}\text { February } 4 \\
15: 20: 45.3 \\
3.4\end{array}$ \\
\hline Stations & \multicolumn{8}{|c|}{$P$ travel times } \\
\hline $\mathrm{H}$ & 1.4 & 0.9 & 1.6 & 1.0 & 1.0 & 1.2 & 1.0 & 1.9 \\
\hline CL. & 9.0 & 8.7 & 9.0 & 8.9 & 9.4 & 9.0 & 8.9 & 8.8 \\
\hline Is $\ldots \ldots \ldots$ & 10.6 & 10.6 & 10.8 & 10.7 & 10.6 & 10.7 & 10.7 & 10.7 \\
\hline$W \ldots \ldots$ & $\ldots$ & 13.3 & 14.0 & 14.0 & 13.9 & 13.8 & 13.9 & 14.4 \\
\hline $\mathrm{T}$. & 16.4 & 16.2 & 16.2 & 16.3 & 16.2 & 16.2 & 16.3 & 15.5 \\
\hline FT. & $\ldots$ & $\cdots$ & $\ldots$ & 26.5 & 26.0 & $\ldots$ & $\ldots$ & 25.9 \\
\hline $\mathrm{Kg}$. & 29.1 & 29.9 & 29.9 & 29.0 & 29.0 & $\ldots$ & 29.0 & 29.7 \\
\hline MW... & 33.0 & $\ldots$ & $\ldots$ & 34.5 & 34.1 & 34.7 & 33.8 & 36.5 \\
\hline D.. & $\ldots$ & $\ldots$ & $\ldots$ & $\ldots$ & $\ldots$ & 35.4 & 36.4 & 33.9 \\
\hline P. . & 34.2 & $\ldots$ & $\ldots$ & 34.7 & 34.9 & 35.1 & 34.3 & 34.4 \\
\hline SB. & 39.0 & $\ldots$ & .. & 39.4 & 38.1 & 41.1 & 39.6 & 41.4 \\
\hline R. . & 36.9 & $\ldots$ & $\cdots$ & 37.3 & 37.1 & 38.8 & 37.1 & 36.6 \\
\hline PV. & 38.0 & $\ldots$ & $\ldots$ & $\ldots$ & $\cdots$ & $\cdots$ & $\ldots$ & $\ldots$ \\
\hline $\operatorname{Pr}$. & 47.6 & $\ldots$ & .. & 47.8 & 47.8 & 47.7 & 47.6 & 47.5 \\
\hline Hf. & $\ldots$ & $\ldots$ & $\ldots$ & 53.3 & $\ldots$ & $\ldots$ & 48.3 & 57.6 \\
\hline \multirow[t]{2}{*}{ Bt. . . . . . } & 56.9 & $\ldots$ & $\ldots$ & 56.9 & 57.4 & 60.9 & 57.2 & 56.7 \\
\hline & \multicolumn{8}{|c|}{$\mathbf{S}$ travel times } \\
\hline H. & 3.2 & 2.3 & 3.6 & 2.7 & 2.9 & 3.9 & 2.9 & 3.4 \\
\hline CL. & $\ldots$ & 15.6 & 15.3 & 15.5 & 16.0 & 15.6 & $\ldots$ & 15.4 \\
\hline Is. . & 19.2 & $\ldots$ & $\ldots$ & 19.1 & $\ldots$ & 14.3 & $\ldots$ & 18.6 \\
\hline W. & $\ldots$ & 24.2 & 24.5 & 24.3 & 24.2 & 23.4 & 24.1 & 25.0 \\
\hline $\mathrm{T}$. & 28.2 & 28.5 & 28.8 & 28.6 & 28.6 & 28.4 & 28.5 & 27.6 \\
\hline FT. & $\ldots$ & $\ldots$ & .. & 45.1 & 42.6 & $\ldots$ & $\ldots$ & 45.0 \\
\hline $\mathrm{Kg}$ & 50.1 & 52.9 & 52.1 & 52.7 & 51.9 & $\ldots$ & 51.9 & 52.6 \\
\hline
\end{tabular}

a Station abbreviations: Barret, Bt; China Lake, CL; Dalton, D; Fort Tejon, FT; Haiwee, H; Hayfield, Hf; Isabella, Is; King Raneh, Kg; Mount Wilson, MW; Palomar, Pr; Palos Verdes, PV; Pasadena, P; Riverside, R; Santa Barbara, SB; Tinemaha, $T$; and Woody, $W$. 
TABLE 3

P and S Travec Times for Representative Shocks with Epicenter

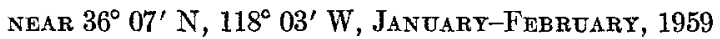

\begin{tabular}{|c|c|c|c|}
\hline 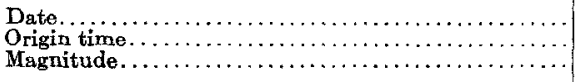 & $\begin{array}{l}\text { January } 6 \\
16: 10: 20.6 \\
3.7\end{array}$ & $\begin{array}{l}\text { January } 16 \\
00: 10 ; 05.9 \\
\quad 4.3\end{array}$ & $\begin{array}{c}\text { February } 8 \\
08: 28: 55.7 \\
3.5\end{array}$ \\
\hline Station & \multicolumn{3}{|c|}{ P travel times } \\
\hline 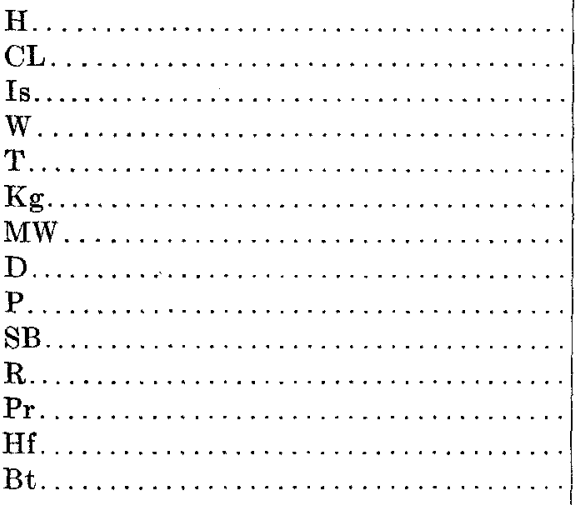 & $\begin{array}{r}1.1 \\
9.2 \\
10.3 \\
14.0 \\
16.8 \\
29.8 \\
35.5 \\
\ldots \ldots \\
36.2 \\
40.5 \\
36.9 \\
48.2 \\
\ldots \ldots \\
57.2\end{array}$ & $\begin{array}{r}0.8 \\
8.5 \\
10.3 \\
13.7 \\
16.8 \\
28.7 \\
\ldots . \\
33.5 \\
33.6 \\
38.2 \\
36.2 \\
47.0 \\
\ldots \\
56.4\end{array}$ & $\begin{array}{r}0.9 \\
\ldots \ldots \\
10.0 \\
13.9 \\
16.8 \\
\ldots \ldots \\
33.6 \\
33.9 \\
33.8 \\
44.0 \\
36.2 \\
52.4 \\
57.5 \\
56.3\end{array}$ \\
\hline Bt. $\ldots \ldots \ldots \ldots \ldots \ldots \ldots \ldots \ldots \ldots$ & \multicolumn{3}{|c|}{ S travel times } \\
\hline 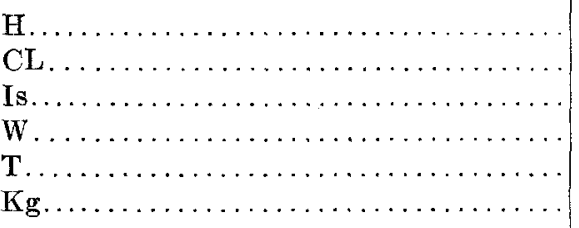 & $\begin{array}{l}2.6 \\
18.4 \\
24.0 \\
29.0 \\
59.8\end{array}$ & $\begin{array}{r}2.5 \\
17.6 \\
23.4 \\
28.9 \\
52.8\end{array}$ & $\begin{array}{l}1.9 \\
\ldots \\
\ldots \\
24.0 \\
30.4 \\
\ldots\end{array}$ \\
\hline
\end{tabular}

TABLE 4

Data for Earthquake of Jandary 5, 1959, 12:36:02.9, Referred to $36^{\circ} 09^{\prime} \mathrm{N}, 118^{\circ} 03^{\prime} \mathrm{W}$

\begin{tabular}{|c|c|c|c|c|c|c|c|c|c|}
\hline Station & $\underset{12: 36}{P}$ & $\Delta$ & $\underset{(h=16 \mathbf{k m} .)}{P}$ & $\begin{array}{c}0 \\
12: 36\end{array}$ & $\Delta / 8.2$ & $\mathrm{P}-\Delta / 8.2$ & $S-P$ & $1.37(\mathrm{~S}-\mathrm{P})$ & $\begin{array}{c}\mathrm{O} \\
12: 36\end{array}$ \\
\hline $\mathrm{H}$. & 4.3 & 9.4 & 2.9 & 1.4 & $\ldots$ & $\ldots$ & 1.8 & 2.5 & 1.8 \\
\hline CL. & 11.9 & 55.2 & 9.0 & 2.9 & . & $\ldots$ & $\ldots$ & $\cdots$ & $\ldots$ \\
\hline Is. . & 13.5 & 66.2 & 10.7 & 2.8 & $\ldots$ & $\ldots$ & 8.6 & $11.8^{\prime}$ & 1.7 \\
\hline T. & 19.3 & 101.6 & 16.2 & 3.1 & 12.4 & 6.9 & 11.8 & 16.2 & 3.1 \\
\hline Kg... & 32.0 & 178.4 & 28.3 & 3.7 & 21.7 & 10.3 & 21.0 & 28.8 & 3.2 \\
\hline MW. . & 35.9 & 213.7 & 33.8 & 2.1 & 26.1 & 9.8 & $\ldots$ & $\ldots$ & $\ldots$ \\
\hline P.. & 37.1 & 222.3 & 35.2 & 1.9 & 27.1 & 10.0 & $\cdots$ & $\ldots$ & $\cdots$ \\
\hline SB... & 41.9 & 242.6 & 38.4 & 3.5 & 29.6 & 12.3 & $\ldots$ & $\ldots$ & $\ldots$ \\
\hline R.... & 39.8 & 247.0 & 39.1 & 0.8 & 30.1 & 9.8 & $\ldots$ & $\ldots$ & $\ldots$ \\
\hline PV. & 40.9 & 266.8 & $\ldots$ & $\ldots$ & 32.5 & 8.4 & $\cdots$ & $\ldots$ & $\ldots$ \\
\hline Pr. & 50.5 & 328.7 & $\ldots$ & $\ldots$ & 40.1 & 10.4 & $\cdots$ & $\ldots$ & $\ldots$ \\
\hline Bt. & 59.3 & 405.2 & $\ldots$ & $\ldots$ & 49.4 & 9.9 & $\ldots$ & $\ldots$ & $\ldots$ \\
\hline
\end{tabular}


TABLE 5

Data for Earthquake of JaNtary $11,1959,18: 54: 58.1$, RfFerred to $36^{\circ} 09^{\prime} \mathrm{N}, 118^{\circ} 03^{\prime} \mathrm{W}$

\begin{tabular}{|c|c|c|c|c|c|c|c|c|c|}
\hline Station & $\underset{18: 54}{P}$ & $\Delta$ & $\underset{(h=16 \mathrm{~km} .)}{\mathrm{P}-\mathrm{O}}$ & $\underset{18: 54}{O}$ & $\Delta / 8.2$ & $\mathrm{P}-\Delta / 8.2$ & $s-P$ & $1.37(\mathrm{~S}-\mathrm{P})$ & $\underset{18: 54}{O}$ \\
\hline $\mathrm{H}$. & 59.1 & 9.4 & 2.9 & 56.2 & $\ldots$ & $\ldots$ & 1.7 & 2.3 & 56.8 \\
\hline CL.. & 67.0 & 55.2 & 9.0 & 58.0 & & & 6.6 & 9.0 & 58.0 \\
\hline Is. . & 68.8 & 66.2 & 10.7 & 58.1 & $\ldots$ & $\ldots$ & 8.4 & 11.5 & 57.3 \\
\hline W. & 72.1 & 87.5 & 14.0 & 58.1 & $\ldots$ & $\ldots$ & 10.3 & 14.1 & 58.0 \\
\hline $\mathrm{T}$ & 74.4 & 101.6 & 16.2 & 58.2 & 12.4 & 2.0 & 12.3 & 16.8 & 57.6 \\
\hline FT. & 84.6 & 161.0 & 25.5 & 59.1 & 19.6 & 5.0 & 18.6 & 25.5 & 59.1 \\
\hline $\mathrm{Kg}$. & 87.1 & 178.4 & 28.3 & 58.8 & 21.7 & 5.4 & $\ldots$ & $\cdots$ & $\ldots$ \\
\hline MW & 92.6 & 213.7 & 33.8 & 58.8 & 26.1 & 6.5 & $\ldots$ & $\ldots$ & $\ldots$ \\
\hline P. . & 92.8 & 222.3 & 35.2 & 57.6 & 27.1 & 5.7 & $\cdots$ & $\cdots$ & $\cdots$ \\
\hline SB. & 97.5 & 242.6 & 38.4 & 59.1 & 29.6 & 6.9 & $\ldots$ & $\ldots$ & $\ldots$ \\
\hline R. . & 95.4 & 247.0 & 39.1 & 56.3 & 30.1 & 5.3 & $\ldots$ & $\ldots$ & $\cdots$ \\
\hline Pr. & 105.9 & 328.7 & $\ldots$ & $\ldots$ & 40.1 & 5.8 & $\ldots$ & $\ldots$ & $\ldots$ \\
\hline Hf. & 111.4 & 349.4 & $\ldots$ & $\ldots$ & 42.6 & 8.8 & $\cdots$ & $\ldots$ & $\ldots$ \\
\hline Bt.. & 115.0 & 405.2 & $\ldots$ & $\ldots$ & 49.4 & 5.6 & $\cdots$ & $\ldots$ & $\ldots$ \\
\hline
\end{tabular}

TABLE 6

Data for Earthquake of Jandary $16,1959,00: 10: 05.9$, Referred to $36^{\circ} 07^{\prime} \mathrm{N}, 118^{\circ} 03^{\prime} \mathrm{W}$

\begin{tabular}{|c|c|c|c|c|c|c|c|c|c|}
\hline Station & $\underset{00: 10}{P}$ & $\Delta$ & $\underset{(h=16 \mathrm{~km} .)}{\mathrm{P}}-\mathrm{O}$ & $\underset{00: 10}{O}$ & $\Delta / 8.2$ & $\mathrm{P}-\Delta / 8.2$ & $\mathbf{S}-\mathbf{P}$ & $1.37(S-P)$ & $\underset{00: 10}{O}$ \\
\hline H. . & 6.7 & 9.5 & 2.9 & 3.8 & . & . & 1.7 & 2.3 & 4.4 \\
\hline CL. & 14.4 & 52.8 & 8.7 & 5.7 & $\ldots$ & $\ldots$ & $\ldots$ & $\ldots$ & $\ldots$ \\
\hline Is. . . . . & 16.2 & 63.2 & 10.3 & 5.9 & . & 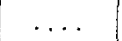 & 7.3 & 10.0 & 6.2 \\
\hline W. & 19.6 & 85.5 & 13.7 & 5.9 & $\ldots$ & $\ldots$ & 9.7 & 13.3 & 6.3 \\
\hline $\mathrm{T}$ & 22.7 & 105.2 & 16.8 & 5.9 & 12.8 & 9.9 & 12.1 & 16.6 & 6.1 \\
\hline $\mathrm{Kg}$. & 34.6 & 176.6 & 28.0 & 6.6 & 21.6 & 13.0 & $\ldots$ & $\ldots$ & $\ldots$ \\
\hline D.. & 39.4 & 217.0 & 34.3 & 5.1 & 26.5 & 12.9 & & & \\
\hline P. & 39.5 & 218.6 & 34.6 & 4.9 & 26.7 & 12.8 & $\cdots$ & $\cdots$ & $\ldots$ \\
\hline SB. & 44.1 & 239.7 & 37.9 & 6.2 & 29.2 & 14.9 & & & \\
\hline R... & 42.1 & 243.5 & 38.5 & 3.6 & 29.7 & 12.4 & $\cdots$ & & $\ldots$ \\
\hline Pr. & 52.9 & 325.2 & $\ldots$ & $\ldots$ & 39.6 & 13.3 & $\ldots$ & & $\ldots$ \\
\hline Bt. & 62.3 & 401.7 & & $\ldots$ & 49.0 & 13.3 & $\ldots$ & $\ldots$ & $\ldots$ \\
\hline
\end{tabular}

The mechanism of faulting should be related to the directions of first motion at the recording stations. In general these are the same for both groups. Details are as follows:

Haiwee: Direction clear only for January 5, 12:36; January 11, 18:55; January 12, 12:36; compression in all three instances. No direction legible for shocks of the B group.

China Lake: Compression, definite for all shocks of groups A and B.

Isabella: Dilatation in all instances examined except one. For the main shock of January 5 there is a little question because of the large deflection. For some of the others the dilatation is immediately followed by larger compression, and for January 19, 21:46, there is a large clear compression with no sign of dilatation.

Woody: (No information for the main shock); consistently compression, except January 17, 20:05 (large sharp dilatation). 
Fort Tejon: Records mostly defective; two clear dilatations.

Tinemaha: Dilatation, usually rather small and long-period, in all legible cases except the main shock, which shows a large, sharp compression.

King Ranch: Compressions where legible.

Dalton: Consistently compressions.

Pasadena: Compression for the main shock, for January 16, 00:10, and rather doubtfully for a few others.

Riverside: Compression for the main shock and for January 16,00:10; small and uncertain first motion otherwise.

Palomar: Compressions when legible.

Hayfield: Compression for the main shock and for January 16, 00:10.

Barrett: Compression for the main shock and for January 16, 00:10.

There appears to be no simple interpretation for these data.

\section{Earthquakes near China Lake}

Table 7 lists all identified shocks of this group, including the very smallest, for January 6-31 inclusive.

Table 8 gives observed time data for the four shocks of this group of magnitude over 3.

Table 9 shows the working out of the data for the shock of Jamuary $9,06: 41: 03.5$, as referred to an epicenter at $35^{\circ} 46^{\prime} \mathrm{N}, 117^{\circ} 35^{\prime} \mathrm{W}$, with the same general assumptions as made for the shocks near Haiwee. The other shocks of table 8 fit approximately as well. The numerous others of small magnitude, discussed in a later paragraph, cannot differ greatly. All show an apparent $S-P$ interval of 0.8 to 1.2 sec. at China Lake; however, this probably remains true over a range of 10 kilometers in epicentral distance.

$\mathrm{S}-\mathrm{P}$ of 1.1 sec. at China Lake, and 8.7 at Isabella, are given in parentheses in table 9 ; since $\mathrm{S}-\mathrm{P}$ could not be read at those stations for the given shock, they represent smaller shocks of the same group, as recorded on the Benioff seismograms.

The assumptions give origin time 06:41:03.5 from the times of $\mathrm{P}$ at the near stations, while the $\mathrm{S}-\mathrm{P}$ data (with the doubtfully valid exception of Tinemaha) clash with this and give origin time about $06: 41: 04.7$. The discrepancy cannot be removed by changing epicenter or depth, nor by changing the velocity of both $\mathrm{P}$ and $\mathrm{S}$ to retain a usual ratio.

These time data are given for their possible future value for comparison with those of the shocks near Haiwee; because of the smaller magnitude of the largest shock of the group, these data are inferior. This applies particularly to the value of $K$ derived from readings at the more distant stations of the group. If one takes the most plausible value, 11.0, for $\mathrm{P}-\Delta / 8.2$, the adopted origin time implies $K=7.5$, which is comparable with that derived for the Haiwee shocks.

Since even the larger of these shocks are of small magnitude, reliable data on direction of first motion are obtainable only at the nearer stations. At China Lake itself the first motion of three of the larger shocks is too large for direction to be determined; however, for January 7, 20:05, it appears to be a compression, and this is supported by recordings of the numerous smaller shocks, most of which show a small but sharp initial compression immediately followed by larger dilatation. 
EARTHQUAKES IN OWENS VALLEY, JANUARY-FEBRUARY, 1959

TABLE 7

Earthquakes of Magnitude 0 and Over, Jandary 6-31, with Ficenter NEAR $35^{\circ} 46^{\prime} \mathrm{N}, 117^{\circ} 35^{\prime} \mathrm{W}$

\begin{tabular}{|c|c|c|c|c|c|}
\hline Date & Origin time & Magnitude & Date & Origin time & Magnitude \\
\hline $\begin{array}{l}\text { Jan. } 6 \ldots \ldots \ldots \ldots \ldots \\
7 \ldots \ldots \ldots \ldots\end{array}$ & $\begin{array}{l}20: 23 \\
23: 30 \\
00: 20 \\
00: 25 \\
00: 55 \\
02: 07 \\
02: 12 \\
02: 30 \\
02: 34 \\
02: 47 \\
02: 48 \\
03: 00 \\
03: 03 \\
03: 17 \\
03: 26 \\
03: 31 \\
10: 13 \\
12: 45 \\
14: 00 \\
14: 22 \\
17: 44 \\
19: 43 \\
19: 58 \\
20: 03 \\
20: 05 \\
20: 17 \\
20: 54 \\
21: 52 \\
002: 19 \\
02: 02: 34 \\
00: 37 \\
01: 02 \\
01: 21 \\
01: 22 \\
01: 34 \\
01: 56 \\
05: 46\end{array}$ & 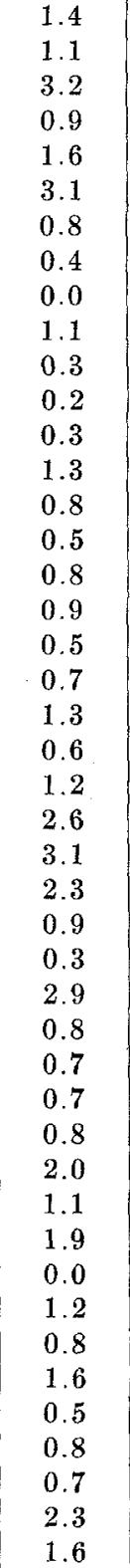 & 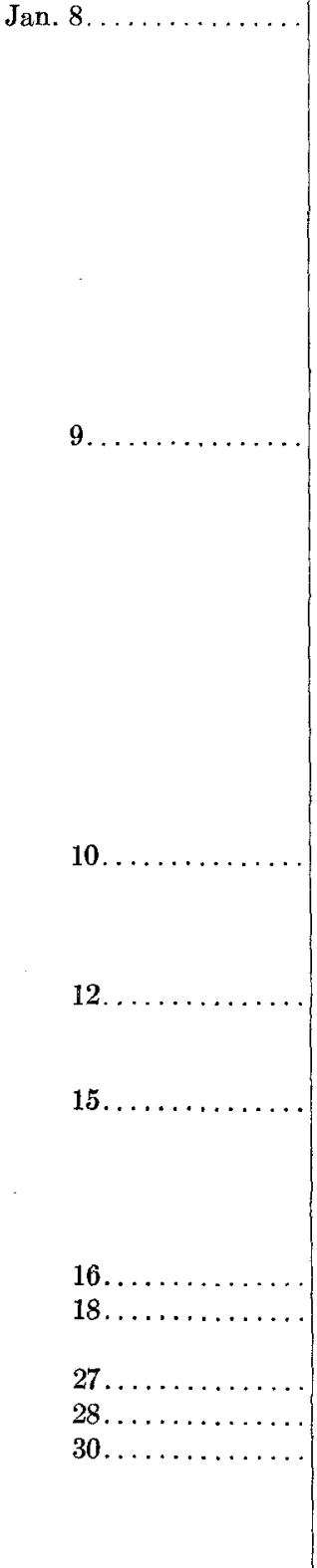 & 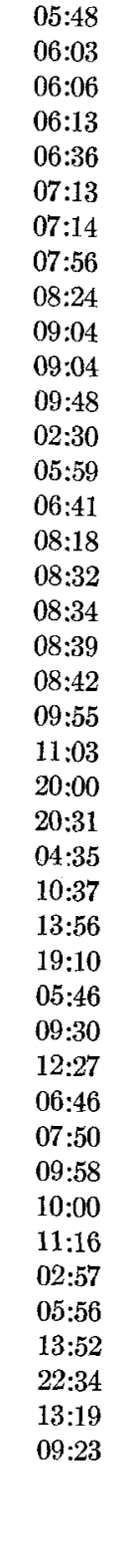 & 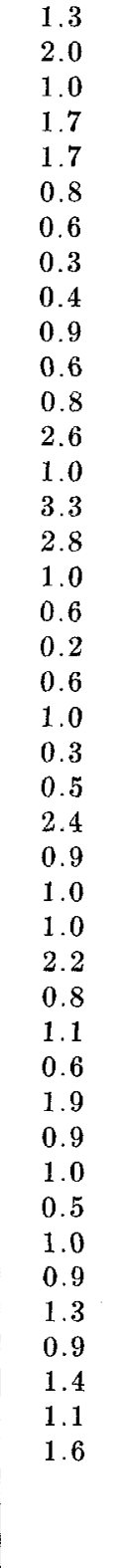 \\
\hline
\end{tabular}


TABLE 8

P and $S$ Travel Times for Representative Shocks with Epicenter NEAR $35^{\circ} 46^{\prime} \mathrm{N}, 117^{\circ} 35^{\prime} \mathrm{W}, \mathrm{J}_{\text {ANUARY }}, 1959$

\begin{tabular}{|c|c|c|c|c|}
\hline 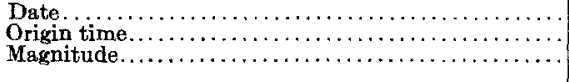 & $\begin{array}{l}\text { January } 7 \\
00: 20: 40.2 \\
\quad 3.2\end{array}$ & $\begin{array}{l}\text { January } 7 \\
02: 07: 17.5 \\
3.1\end{array}$ & $\begin{array}{c}\text { January } 7 \\
20: 04: 39.5 \\
3.1\end{array}$ & $\begin{array}{c}\text { January } 9 \\
06: 41: 03.5 \\
3.3\end{array}$ \\
\hline Station & \multicolumn{4}{|c|}{$P$ travel times } \\
\hline 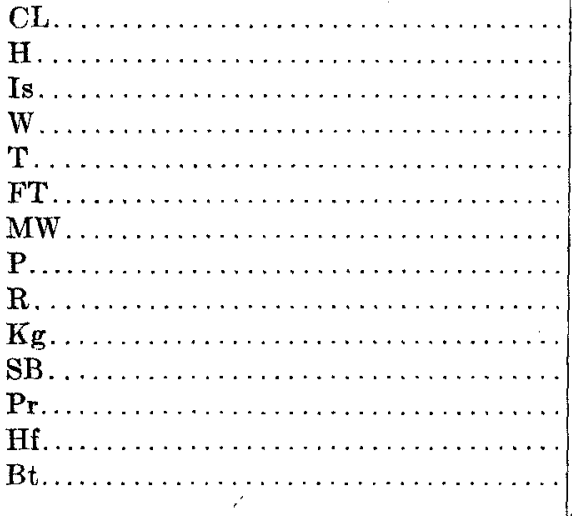 & $\begin{array}{r}2.6 \\
9.0 \\
13.1 \\
18.2 \\
25.7 \\
\ldots . \\
30.2 \\
31.1 \\
34.4 \\
32.9 \\
42.4 \\
41.7 \\
47.4 \\
50.5\end{array}$ & $\begin{array}{r}2.7 \\
8.7 \\
13.3 \\
18.3 \\
26.3 \\
\ldots \ldots \\
30.2 \\
31.9 \\
34.6 \\
33.7 \\
\ldots \ldots \\
41.9 \\
45.4 \\
51.2\end{array}$ & $\begin{array}{r}2.8 \\
9.1 \\
12.8 \\
18.3 \\
26.4 \\
\ldots \\
\ldots \\
32.2 \\
32.6 \\
33.2 \\
\ldots \\
43.1 \\
52.2 \\
\ldots\end{array}$ & $\begin{array}{r}2.7 \\
8.8 \\
13.1 \\
18.2 \\
26.4 \\
25.7 \\
30.6 \\
31.2 \\
31.5 \\
33.2 \\
43.2 \\
41.8 \\
\ldots . . \\
50.8\end{array}$ \\
\hline Bt............ & \multicolumn{4}{|c|}{ S travel times } \\
\hline 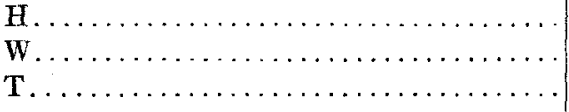 & $\begin{array}{l}15.3 \\
30.5 \\
45.0\end{array}$ & $\begin{array}{l}15.1 \\
30.9 \\
45.3\end{array}$ & $\begin{array}{l}15.0 \\
30.6 \\
45.5\end{array}$ & $\begin{array}{l}15.1 \\
30.4 \\
45.6\end{array}$ \\
\hline
\end{tabular}

TABLE 9

Data For Eartiquake of Januart $9,1959,06: 41: 03.5$, Referred to $35^{\circ} 46^{\prime} \mathrm{N}, 117^{\circ} 35^{\prime} \mathrm{W}$

\begin{tabular}{|c|c|c|c|c|c|c|c|c|c|}
\hline Station & $\underset{06: 41}{P}$ & $\Delta$ & $\left|\begin{array}{c}\mathrm{P} \\
(h=16 \mathrm{~km} .)\end{array}\right|$ & $\underset{06: 41}{0}$ & $\Delta / 8.2$ & $\mathrm{P}-\Delta / 8.2$ & $\mathbf{S}-\mathbf{P}$ & $1.37(\mathrm{~S}-\mathrm{P})$ & $\underset{06: 41}{0}$ \\
\hline CL & 6.2 & 5.6 & 2.7 & 3.5 & & & (1.1) & $(1.5)$ & $(4.7)$ \\
\hline $\mathrm{H}$. & 12.3 & 52.8 & 8.7 & 3.6 & $\ldots$ & & 5.7 & 7.8 & 4.5 \\
\hline Is. . & 16.6 & 81.3 & 13.1 & 3.5 & $\ldots$ & $\ldots$ & $(8.7)$ & (11.9) & $(4.7)$ \\
\hline$W$. & 21.7 & 114.7 & 18.3 & 3.4 & $\ldots$ & $\ldots$ & 12.2 & 16.7 & 5.0 \\
\hline $\mathrm{T}$. & 29.9 & 154.2 & 24.4 & 5.5 & 18.8 & 11.1 & 19.2 & 26.3 & 3.6 \\
\hline FT. & 29.2 & 155.0 & 24.6 & 4.6 & 18.9 & 10.3 & 20.2 & 27.7 & 1.5 \\
\hline $\mathrm{MW}$ & 34.1 & 176.5 & 28.0 & 6.1 & 21.6 & 12.5 & $\ldots$ & $\ldots$ & $\ldots$ \\
\hline P. & 34.7 & 187.4 & 29.7 & 5.0 & 22.8 & 11.9 & $\ldots$ & $\ldots$ & $\ldots$ \\
\hline R.. & 35.0 & 197.6 & 31.3 & 3.7 & 24.1 & 10.9 & $\ldots$ & $\ldots$ & $\ldots$ \\
\hline $\mathrm{Kg}$. & 36.7 & 201.9 & 32.0 & 4.7 & 24.6 & 12.1 & $\ldots$ & $\ldots$ & .. \\
\hline SB.. & 46.7 & 243.7 & 38.5 & 8.2 & 29.8 & 16.9 & $\ldots$ & $\ldots$ & $\ldots$ \\
\hline Pr. & 45.3 & 275.7 & $\ldots$ & $\ldots$ & 33.6 & 11.7 & $\ldots$ & $\ldots$ & $\ldots$ \\
\hline Bt. & 54.3 & 352.5 & .. & $\ldots$ & 43.0 & 11.3 & $\ldots$ & $\ldots$ & $\ldots$ \\
\hline
\end{tabular}


At Haiwee three of the four larger shocks recorded with initial compression; recording for the other was imperfect. Isabella and Woody show compressions consistently. At Tinemaha the shocks of January 7, 00:20 and 02:07, show initial compressions; for the others the first small motion is confused by microseisms.

These data are insufficient for fault-plane work, although they can be inspected for consistency with any hypothesis based on geological field data.

TABLE 10

Numbers of Shocks of Given Magnitudes near China Lake, JANUARY $7-16,1959$

\begin{tabular}{c|c||c|c}
\hline Magnitude & Number & Magnitude & Number \\
\hline 3.3 & 1 & 1.3 & 3 \\
3.2 & 1 & 1.2 & 2 \\
3.1 & 2 & 1.1 & 3 \\
3.0 & 0 & 1.0 & 8 \\
2.9 & 1 & 0.9 & 7 \\
2.8 & 1 & 0.8 & 10 \\
2.7 & 0 & 0.7 & 5 \\
2.6 & 2 & 0.6 & 6 \\
2.5 & 0 & 0.5 & 5 \\
2.4 & 1 & 0.4 & 2 \\
2.3 & 2 & 0.3 & 5 \\
2.2 & 1 & 0.2 & 2 \\
2.1 & 0 & 0.1 & 0 \\
2.0 & 2 & 0.0 & 2 \\
1.9 & 2 & -0.1 & 0 \\
1.8 & 0 & & \\
1.7 & 2 & & \\
1.6 & 3 & & \\
1.5 & 0 & & \\
1.4 & 0 & & \\
\hline
\end{tabular}

Minimal Earthquakes

The chief interest of the China Lake series of shocks is in its bearing on the problem of minimal earthquakes. The Benioff vertical-component instrument at China Lake records with high magnification and very low background disturbance; at the given short epicentral distance $(6 \mathrm{~km}$.) very small disturbances are clearly registered. $\mathrm{Mr}$. Mauger studied the statistical distribution of recorded maximum amplitude and related it to the magnitude scale by comparison with amplitudes recorded at Haiwee and other stations. No standard torsion instrument is operated at China Lake, but magnitudes could be assigned to the larger shocks of the group using the whole group of stations in the usual way, after which magnitudes could be assigned to the smaller ones by comparison of amplitudes recorded at China Lake.

It was at once observed that the number of shocks found on the records increased with decreasing recorded amplitude only down to amplitudes near one millimeter. Definitely fewer shocks were found with amplitudes below one millimeter, although those seen were clearly measurable and much larger than the background disturbance. 
The study of the recording of the larger shocks of the group at other stations led to the calibration formula

$$
M=0.7+\log A
$$

where $A$ is the measured trace amplitude on the record of the Benioff verticalcomponent instrument at China Lake, expressed in millimeters. Thus for a trace amplitude of one millimeter the magnitude is 0.7 , and shocks of lower magnitude than this appear relatively fewer. Only a few shocks were found with amplitudes as low as $0.2 \mathrm{~mm}$. (magnitude 0 ).

Such a cutting off of small shocks for low magnitudes may be anticipated theoretically; but in previous investigations in California the numbers of shocks were found to increase regularly with decreasing magnitude down to approximately the zero of the scale, with no sign of a cutoff. ${ }^{1}$

Table 10 shows the statistical distribution in magnitude for ten days, January $7-16$ inclusive, as derived from table 7 . The frequency maximum near magnitude 0.8 is obvious.

Dr. K. Aki has remarked to the writer that some of the effect may be due to the response curve of the Benioff seismometer, which has a high peak near 0.2 second, the period of the galvanometer. Small shocks with most of their energy in very short periods might then write comparatively small records. However, the investigations cited above, in which the number of shocks recorded went on increasing smoothly down to magnitude zero, used the records of precisely similar instruments.

\section{EARLIER SHOCKS}

To clarify the relation between the Haiwee and China Lake group of shocks, the China Lake records of earlier dates were searched for small shocks near the station. Two on January 6, at 20:23 (magnitude 1.4), and 23:30 (magnitude 1.1), may be regarded as foreshocks of the principal series beginning on January 7 , at $00: 21$. None were found on January 4 or 5 . From December 1 through January 3 , twenty-three such shocks of magnitudes ranging from 0.2 to 1.8 were identified; thirteen of them occurred on December 6 and 7 , with magnitudes from 0.3 to 1.3 .

Only five of these shocks (magnitudes 0.9 to 1.3 ) were recorded from January 17 to 31 inclusive.

\section{ACKNOWLEDGMENTS}

The work reported in this paper was supported by National Science Foundation project NSF-G6065.

The writer is much indebted to his assistants under the project: Mr. Richard Mauger, Mr. John K. Gardner, and Mr. William Thompson.

${ }^{1}$ C. F. Richter and J. M. Nordquist, "Minimal Recorded Earthquakes," Bull. Seism. Soc. Am., 38: 257-261 (1948),

Seismological Laboratory,

California Institute of Technologt,

Pasadena, Camifornta.

Contribution no. 944 .

Project NSF-G6065, Seismicity of southern California. 